\author{
Kamil Stachowski \\ Jagiellonian University in Kraków
}

\title{
An Experiment in Labelling Draw-a-Map Maps
}

\begin{abstract}
Apart from offering a contribution to perceptual dialectology of Poland, the paper discusses an experiment in which two groups were set a map drawing task. One group was given a map on which major cities were marked while the other a map with the main regions. The two maps combined from their answers have proven to be nothing alike, suggesting that this one detail in the design of the study can dramatically influence its results, and as such it needs to be paid particular attention and further investigated.
\end{abstract}

\section{Keywords}

perceptual dialectology, draw-a-map, methodology, Polish language

\section{Streszczenie}

Artykuł jest przyczynkiem do dialektologii percepcyjnej Polski, ale przede wszystkim dyskusją wyników eksperymentu, w którym dwie grupy poproszono o wypełnienie map. Jednej przedstawiono mapy z zaznaczonymi głównymi miastami, drugiej - z głównymi regionami geograficznymi. Mapy powstałe przez scalenie ich odpowiedzi okazały się diametralnie różne, co sugeruje, że ten jeden szczegół w sposobie przygotowania kwestionariusza może bardzo istotnie wpłynąć na wyniki badania, i jako taki winien być starannie przemyślany i dokładniej przebadany.

\section{Słowa kluczowe}

dialektologia percepcyjna, draw-a-map, metodologia, język polski

\section{Introduction}

The field of perceptual dialectology concerns itself with how non-linguists perceive dialects and dialectal variation. It began in 1930s in the Netherlands but only gained greater impetus in 1980s and 1990s, owing to the works of D.R. Preston. One of the five methods he proposed is called draw-a-map (1989:25); its basic idea is that respondents are given a map of the region under scrutiny, and are asked to mark in it the areas where they believe people speak differently, incorrectly, funny, \&c. Their answers are then superimposed to create a 
single heatmap or contour map which can be viewed as a graphical representation of the popular perception of dialects and dialectal variation.

One crucial detail which may, as shown by this paper, thoroughly alter the result of the study, is what kind of map respondents are given to mark dialect boundaries on. If it contains too many details, it can be confusing and unintenionally suggest answers; if it contains too little, respondents will only be able to draw on it in crude approximation and the combined result will likely be very inaccurate. Preston (1989: 25) mentions that in one of his surveys some respondents appeared to believe (wrongly) that dialect ranges coincide with state borders in the USA. Cukor-Avila et al. (2012: 12) performed a pilot study in Texas in which they used five different maps (with cities, cities and highways, counties, major regions, and blank ones), and obtained different results; unfortunately, they do not discuss them in detail. Similarly, Alhazmi (2017) used two different maps for her study in Saudi Arabia (with cities and the desert, and blank ones), and obtained different results which she, too, does not review in detail. It is only from one of the anonymous reviewers that I learned about Lameli, Purschke and Kehrein (2008), a study conducted in Marburg, Germany in 2005 and designed specifically to evaluate the effect that the labelling on the maps handed out to respondents has on their answers. They prepared as many as seven types of maps (with country borders, topography, rivers, state borders, major cities, cities and towns, and mixed ones with state borders, rivers, cities and towns), and found that the results varied quite significantly. It is therefore unfortunate that the differences in handling of the data, and generally in the adopted methodology of analysis render that study difficult to directly compare to the one presented in the current paper (one minor example of this different approach is mentioned in fn. 1).

There appears to be no standard practice: some studies employ fine-grained maps (e.g. Geržotaitè and Čepaitienè 2016 marked all 60 municipalities in Lithuania), others are less specific (e.g. cities, waters and mountains as in Calaza Díaz et al. 2015 for Galicia, and Koch 2009 for western Russia), others less specific still (e.g. Theodoropoulou and Tyler 2014 only marked state borders of the Arab-speaking world), others have no more on them than the general region (e.g. Bucholtz et al. 2007 for California), and others leave respondents with entirely blank canvas (e.g. Würth 2014 for Buenos Aires).

The present paper discusses an experiment which was similar in design to Lameli, Purschke and Kehrein (2008), only with fewer types of maps but more respondents for each. It was conducted in 2017 at the Maria CurieSkłodowska University in Lublin, Poland. Two groups of students were given questionnaires in which the only difference were the labels on the map. The "cities map" contained thirteen major cities, the "regions map" twelve of the main geographical and historical regions (Fig. 1). Section 2 discusses the design of the forms, sections 3 and 4 the two parts of the experiment 
separately, section 5 compares them and concludes the experiment, and section 6 summarizes the main points. Some answers were excluded from the main part of the study; these are briefly discussed in the Appendix.

As for the technical side, I used a method which is functionally almost equivalent to those presented in Montgomery and Stoeckle (2013) and Calaza Díaz (2015), only using Adobe Illustrator, and open-source GRASS GIS (grass. osgeo.org) and QGIS (www.qgis.org).

I want to express my gratitude to both all the students who agreed to participate in this experiment, and to all the teachers who were so kind as to donate time from their classes. My particular thanks are due to Radosław Bomba, $\mathrm{PhD}$, for his interest and willing help. I am also grateful to the anonymous reviewers of this paper for their thoroughness and helpful remarks. Naturally, all the remaining errors are mine alone.

\section{Questionnaire}

The questionnaire was designed in such a way as to make possible direct comparison with the findings of Bounds (2010, and what is effectively its repetition from 2015) and Stachowski [forthcoming]. It comprised three parts: social background, map, and comments. See Fig. 1.

The social background was reduced to six questions:

- Age group, choice between $\leq 19,20-29,30-39$, and $\geq 40$;

- Sex;

- Education, choice between secondary and higher;

- Occupation, tickbox for student and a field for other;

- Place of birth; and

- Childhood residence, the place where the respondent spent most of their childhood.

The last question may seem a little inquisitive but I feel it is quite important. While many respondents were born and raised in the same place, or raised in a small village and born in the nearest larger town with a hospital in it, there were also quite a few who were born in one place but raised at the other end of the country. Their perception of the dialectal diversification must surely differ from the view of those who spent their entire lives in one place and so, potentially, it could considerably hurt the representativeness of the study if their answers were mixed.

The map was the second part of the questionnaire, and the core of the experiment. One version, the "cities map", was modelled after the map used by 

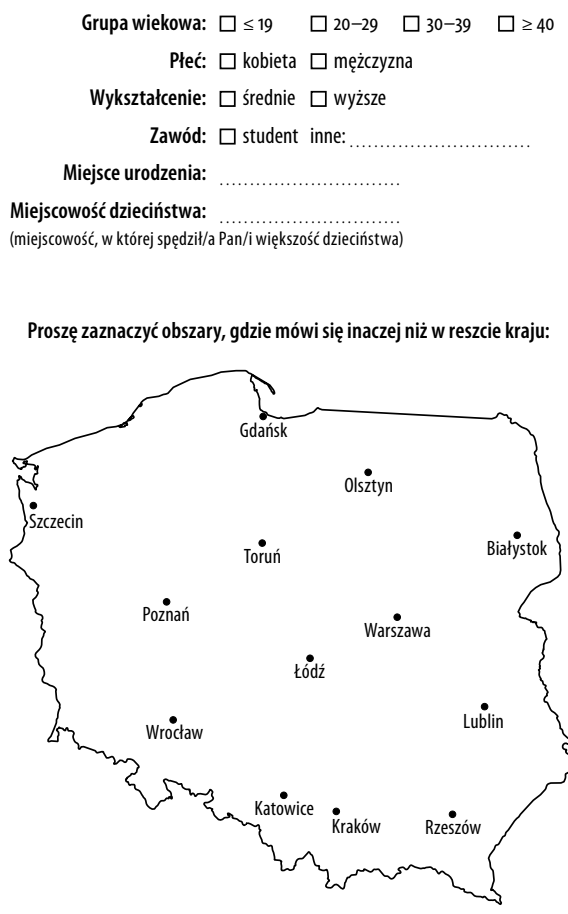

Uwagi:
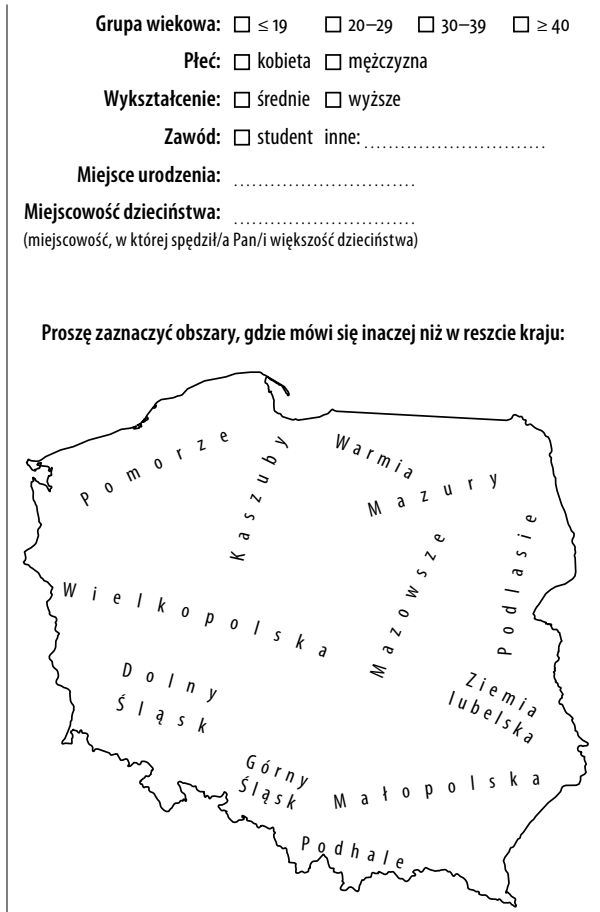

Uwagi:
Bardzo dziękuję!

a) Cities map

\section{Bardzo dziękuję!}

b) Regions map

Figure 1. The questionnaires

Bounds $(2010,2015)$ and Stachowski (forthcoming). It represented thirteen of the major cities so chosen as to be relatively evenly distributed across the country and allow for easy orientation. The other version, the "regions map", contained twelve of the main geographical and historical regions of Poland, also chosen primarily with the ease of orientation in mind.

The instruction above the map said Proszę zaznaczyć obszary, gdzie mówi się inaczej niż $w$ reszcie kraju ('Please mark areas where people speak differently than in the rest of the country'). The word obszary 'areas' was chosen purposefully to encourage respondents to not only encircle or underline the city/region 
names, and also to avoid making suggestions by using a more specific term such as region 'region', which would have been in fact perhaps even more neutral in this context. While I have no way of gauging the effectiveness of this measure with regard to the latter goal, I am afraid it has somewhat failed at the former.

Simlarly, when being asked to fill in the form, students were expressly told that what is being surveyed is their personal, subjective view, that there are no right or wrong answers, and that the questionnaire is anonymous and will have no bearing whatsoever on their final marks. I am nonetheless unable to tell exactly to what degree this has prevented them from looking for inspiration in their neighbours' forms.

Lastly, below the map there was an empty space in which respondents were free to express their views and opinions not bound by the confines of the drawa-map task. See below.

The questionnaire was held among the students of the Marie Curie-Skłodowska University in Lublin, Poland in April 2017. The substantial majority of respondents studied various disciplines within the humanities, but not Polish or any other philology. Overall, I collected 351 forms of which 177 were included in the analysis: 92 out of 160 for the cities map, and 85 out of 191 for the regions map.

Bounds $(2010,2015)$ included all of her questionnaires in the analysis and thus obtained a picture which is perhaps representative to a certain degree of the students of the Adam Mickiewicz University in Poznań, Poland, but not of the inhabitants of Poznań, the Greater Poland voivodeship, or any particular age group. In Stachowski [forthcoming], I chose to limit the analysis to people aged 18-29, with secondary education, currently studying, and born and raised in the West Pomeranian voivodeship. Wishing to keep the two studies comparable, and to reduce as much as possible the number of variables, I applied the same limitations in the main part of the present paper, mutatis mutandis. The questionnaires which have been excluded are briefly summarized in the Appendix.

For age and sex, I discarded both forms with answers outside the 18-29 range, and invalid forms with neither or both fields ticked. Likewise, I rejected all forms in which the respondents indicated they have higher education even though I suspect the majority were just cases of misunderstanding of how the system works - especially that almost $2 / 3$ of them simultaneously selected age $\leq 19$, a point in life at which very few people have already completed their university education. As for occupation, I included all forms with the field student ticked, regardless of any additional jobs sometimes listed in the empty field 
nearby. Lastly, questionnaires filled by students born or raised outside the Lublin voivodeship were also rejected.

The detailed results from the social and map parts of the questionnaire are presented below in sections 3 and 4 . The comments part proved to be inconsequential. Only very few respondents wrote anything at all. Several were comments to the effect that each part of the country has its own local words or phrases and people speak differently everywhere; several were smiley faces, and several said 'you're welcome' under where it said 'thank you very much' at the bottom of the page. The one actually valuable comment was on a form with the cities map, and it read 'I'm Belarusian, but it's more difficult to understand [the dialect] in Poznań.

\section{Cities map}

In total, 160 people filled in the forms with the cities map, out of which I selected 92, as explained in section 2 above (see Appendix for the discarded questionnaires). The social background of the respondents is given in Table 1.

Table 1. The social background of the respondents in the cities part of the experiment. Only the forms with answers in bold were included in the main part of the analysis

\begin{tabular}{|c|c|c|c|c|c|c|c|}
\hline \multicolumn{2}{|c|}{ Age } & \multicolumn{2}{|l|}{ Sex } & \multicolumn{2}{|c|}{ Education } & \multicolumn{2}{|c|}{ Occupation } \\
\hline$\leq 19$ & 25 & female & 95 & secondary & 126 & student & 157 \\
\hline $20-29$ & 132 & male & 64 & higher & 33 & & \\
\hline $30-39$ & 2 & & & & & & \\
\hline$\geq 40$ & 1 & & & & & & \\
\hline other & - & other & 1 & other & 1 & other & 3 \\
\hline & & Place of birth & & Childhood $\mathrm{r}$ & nce & & \\
\hline & & Lublin & 51 & Lublin & 30 & & \\
\hline & & $\begin{array}{l}\text { Lublin } \\
\text { voivodeship }\end{array}$ & 69 & $\begin{array}{l}\text { Lublin } \\
\text { voivodeship }\end{array}$ & 88 & & \\
\hline & & other & 40 & other & 42 & & \\
\hline
\end{tabular}

Let us begin by briefly comparing four subsets: maps filled in only by women (47 respondents), only by men (45), only by people born and raised in Lublin (23), and only by people born and raised in the Lublin voivodeship but outside Lublin itself (69) (Fig. 2). 

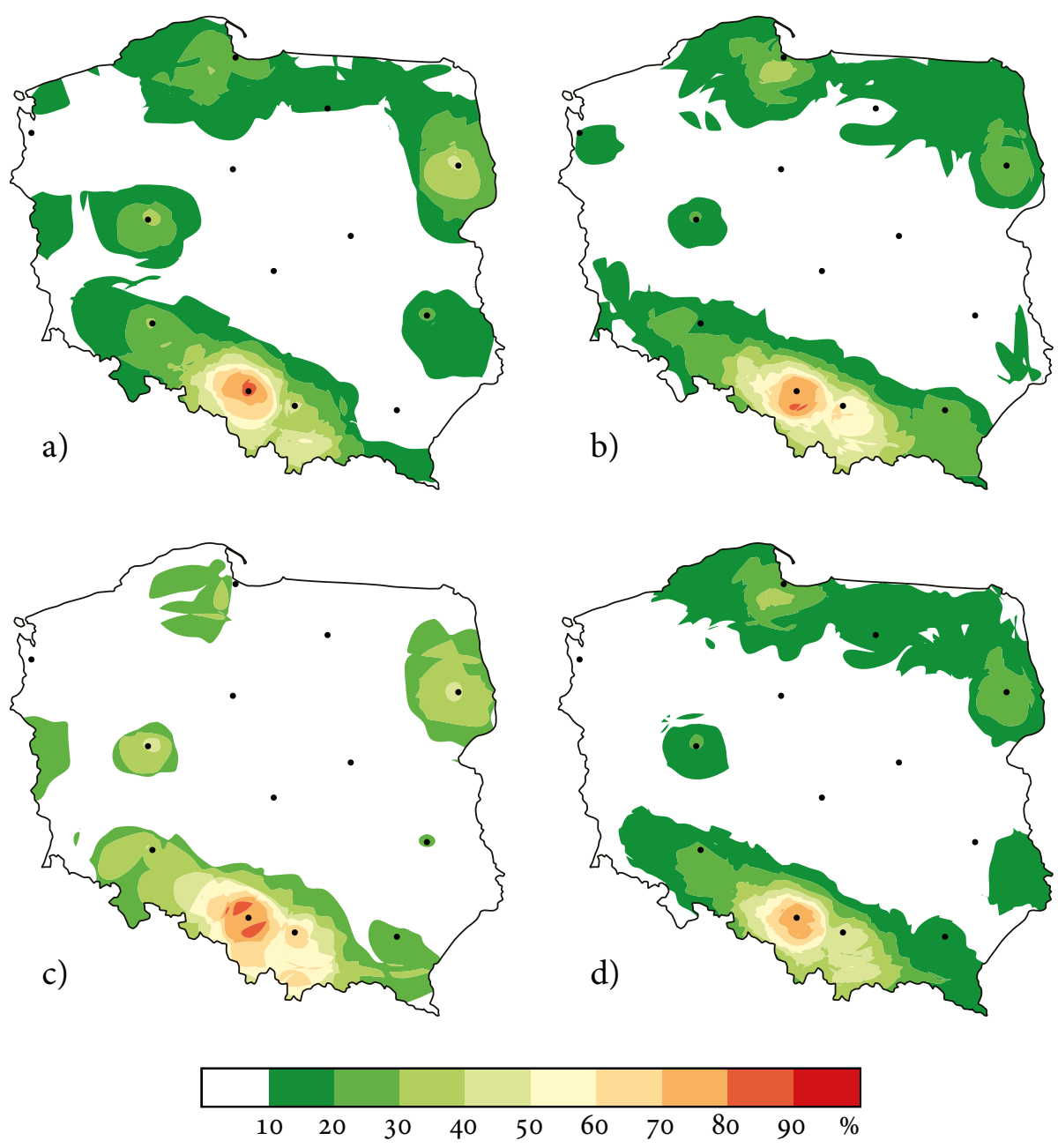

Figure 2. Cities maps filled in by: a) only women (47 respondents), b) only men (45), c) only people born and raised in Lublin (23), and d) only people born and raised in the Lublin voivodeship but outside Lublin (69)

Demirci (2002) found several differences between maps filled in by women and those filled in by men. My previous study, very similar to this one, only conducted in Szczecin (Stachowski [forthcoming]), corroborated only one of those differences, namely that the areas encircled by women tend to be smaller than those marked by men. Interestingly, Montgomery and Stoeckle (2013: 70,72 ) report just the opposite, but it may be that their result was skewed by a very small sample size. Here, I could observe neither this tendency nor in fact any other. It may be that sex simply does not play a greater role in the perception of dialectal variation. However, see also section 4 below. 
The difference between Lublinians and non-Lublinians is much more visible. It would appear that the former have a more punctual view, associated perhaps more with specific cities than with entire regions, and that they are more uniform in their opinion, resulting in a more 'mountainous' map. However, it must be noted that the group of Lublinians counted merely 23 respondents, so it only takes two or three people's questionnaires to change the shade in a map such as the one in Fig. 2c. Also, this tendency did not emerge in an analogous study in Szczecin - though it can perhaps be observed in the regions map (section 4 below).

Now let us look at the final map which combines all the responses (Fig. 5a), clockwise starting from Gdansk.

It is my understanding that the brighter area south-west of Gdansk was meant to denote not the city itself, but actually the region of Kashubia. This is quite reasonable because it is indeed far more common to hear spoken Kashubian in towns and villages than it is in Gdansk or Gdynia. In a study performed in Szczecin (Stachowski [forthcoming]), only less than 30\% of the respondents marked this region which is interesting because one could expect that, being geographically much closer, the inhabitants of the West Pomeranian voivodeship would more readily summon into mind this very clearly different language than would the inhabitants of the Lublin voivodeship. This seems to go against the findings of Gould and White (1986: 23), that interest and emotional involvement decrease together with the square of the geographic distance. Around Olsztyn, Warmia and Masuria are very poorly recognizable, both by the inhabitants of Szczecin, and of Lublin. Białystok, on the other hand, was marked by almost a half of Szczecinians, as compared to less than $40 \%$ of Lublinians. Again, a result that appears to contradict Gould and White. Warsaw and Lublin were marked by less than $20 \%$ of the respondents in both studies, the former being maybe seen as essentially the literary standard of Polish. Rzeszów was marked by less than $20 \%$ of Lublinians and more than $40 \%$ of Szczecinians. It would be my guess that the latter may view the east of the country as preserving to some degree the pre-war eastern dialect of Polish whereas the inhabitants of the Lublin voivodeship know better, but this explanation is undermined by the fact that more than $40 \%$ of the respondents in the Szczecin study marked Białystok and Rzeszów while only less than 20\% marked Lublin, even though it is located just as much to the east as the other two. Cracow was marked by between $50 \%$ and $70 \%$ in both Szczecin and Lublin. I am not sure why this should be. I find it difficult to believe that the respondents would see Cracow as symbolizing the Podhale region, especially seeing as many put Cracow and Katowice in a single ellipsis, but I am at a loss for another explanation. 
It should be also noted that a very comparable number of people marked Podhale separately; the resulting lighter blob is perhaps too small to be easily seen in the map but it was certainly remembered by a much greater proportion of respondents from Lublin than from Szczecin where it was almost entirely omitted. Katowice was expressly the most recognizable city in both studies. I suspect this is because it is strongly associated with the Silesia region, widely known for its cultural and linguistic distinctness. Wrocław was only a little more recognizable in Szczecin than it was in Lublin. It, too, was sometimes encircled together with Katowice, owing perhaps to the fact that both voivodeships have Silesia in their names despite being quite separate in almost every other respect. Łódź was almost never marked in either study. Poznań, on the other hand, was marked by less than $30 \%$ of Lublinians and by more than $70 \%$ of Szczecinians - and also by more than $70 \%$ of Poznanians in Bounds' study (2010: 166, 2015: 40). Surely, inhabitants of the West Pomeranian voivodeship have simply had considerably more contact with the dialect of Greater Poland, not least because when Pomerania was being populated by Poles after World War II, almost $11 \%$ of its new inhabitants came from Greater Poland (NSP, p. 148f, 152). Torun was marked by less than $10 \%$ in both the Lublin and the Szczecin study, and Szczecin itself was marked by less than $20 \%$ of Lublinians and less than $10 \%$ of Szczecinians.

There is very little correlation $(\rho=-0.08)$ between the number of respondents who marked specific cities and the number of Google results for phrases describing their dialect (see section 5, and Table 3). The two by far most frequent phrases are for Poznan and Warsaw which were marked in the map by fewer than $30 \%$ and fewer than $10 \%$ of respondents, respectively. Conversely, the most distinctly marked city, Katowice with more than $70 \%$ of the votes, seems almost never to appear paired with gwara, dialect, or język. In this case, I suspect that Katowice was not marked in the map as such but more as a symbol for the entire region of Upper Silesia (cf. section 4). The near absence of Poznań and Warsaw, however, is more baffling. It will be perhaps interesting to mention that in similar studies performed in Szczecin (Stachowski [forthcoming]) and in Poznań (Bounds 2010, 2015), Poznań was marked by more than $70 \%$ of respondents and Warsaw by more than $10 \%$ and $30 \%$, respectively. On the other hand, the regions map appears to follow Table 3 quite closely; see section 5 for a possible explanation.

Overall, the maps drawn by Lublinians and Szczecinians are not too dissimilar and certain general patterns begin already to emerge, which, in addition, seem to correspond approximately to Bounds' findings from Poznań. However, I suggest that the first two studies be treated separately from the third one because of their different approach to demographics (see sec. 2). It is too early to draw far-reaching conclusions yet, and I believe such studies should not only be continued but also complemented with interviews in which respondents are 
encouraged to elaborate on actually why they encircled the cities that they did. I suspect many will find it difficult to articulate clearly their reasons but without this it seems to me that we will remain forever reduced to guessing.

\section{Regions map}

In total, 191 people filled in the forms with the regions map, out of which I selected 85, as explained in section 2 above (see Appendix for the discarded questionnaires). The social background of the respondents is given in Table 2.

Table 2. The social background of the respondents in the regions part of the experiment. Only the forms with answers in bold were included in the main part of the analysis

\begin{tabular}{|c|c|c|c|c|c|c|c|}
\hline \multicolumn{2}{|c|}{ Age } & \multicolumn{2}{|l|}{ Sex } & \multicolumn{2}{|c|}{ Education } & \multicolumn{2}{|c|}{ Occupation } \\
\hline$\leq 19$ & 21 & female & 114 & secondary & 152 & student & 181 \\
\hline $20-29$ & 165 & male & 75 & higher & 37 & & \\
\hline $30-39$ & 3 & & & & & & \\
\hline$\geq 40$ & 1 & & & & & & \\
\hline other & 1 & other & 2 & other & 2 & other & 10 \\
\hline & & Place of birth & & Childhood $\mathrm{r}$ & ence & & \\
\hline & & Lublin & 62 & Lublin & 32 & & \\
\hline & & $\begin{array}{l}\text { Lublin } \\
\text { voivodeship }\end{array}$ & 74 & $\begin{array}{l}\text { Lublin } \\
\text { voivodeship }\end{array}$ & 75 & & \\
\hline & & other & 55 & other & 84 & & \\
\hline
\end{tabular}

Let us once again begin with a brief comparison of four subsets: maps filled in by only women (50 respondents), by only men (35), by only people born and raised in Lublin (21), and by people born and raised in the Lublin voivodeship, though not in Lublin itself (64) (Fig. 3).

Cities maps filled in by women and by men were hardly different (see section 3 above). With the regions map, it seems that men maybe tend to encircle somewhat more regions than women since Fig. $3 \mathrm{~b}$ appears to be overall more filled than 3a, but in the light of the differing results adduced in 3, I would be more willing to ascribe this to mere chance than a stable tendency, until more data are collected to support the latter claim.

The difference between Lublinians and non-Lublinians appears to be similar in this regard. This is consistent with what we saw in the cities map ( 3 above) but, again, it should be noted that Fig. $3 \mathrm{c}$ is based on a relatively small sample of 21 people, not sufficient to support a reliable conclusion. 

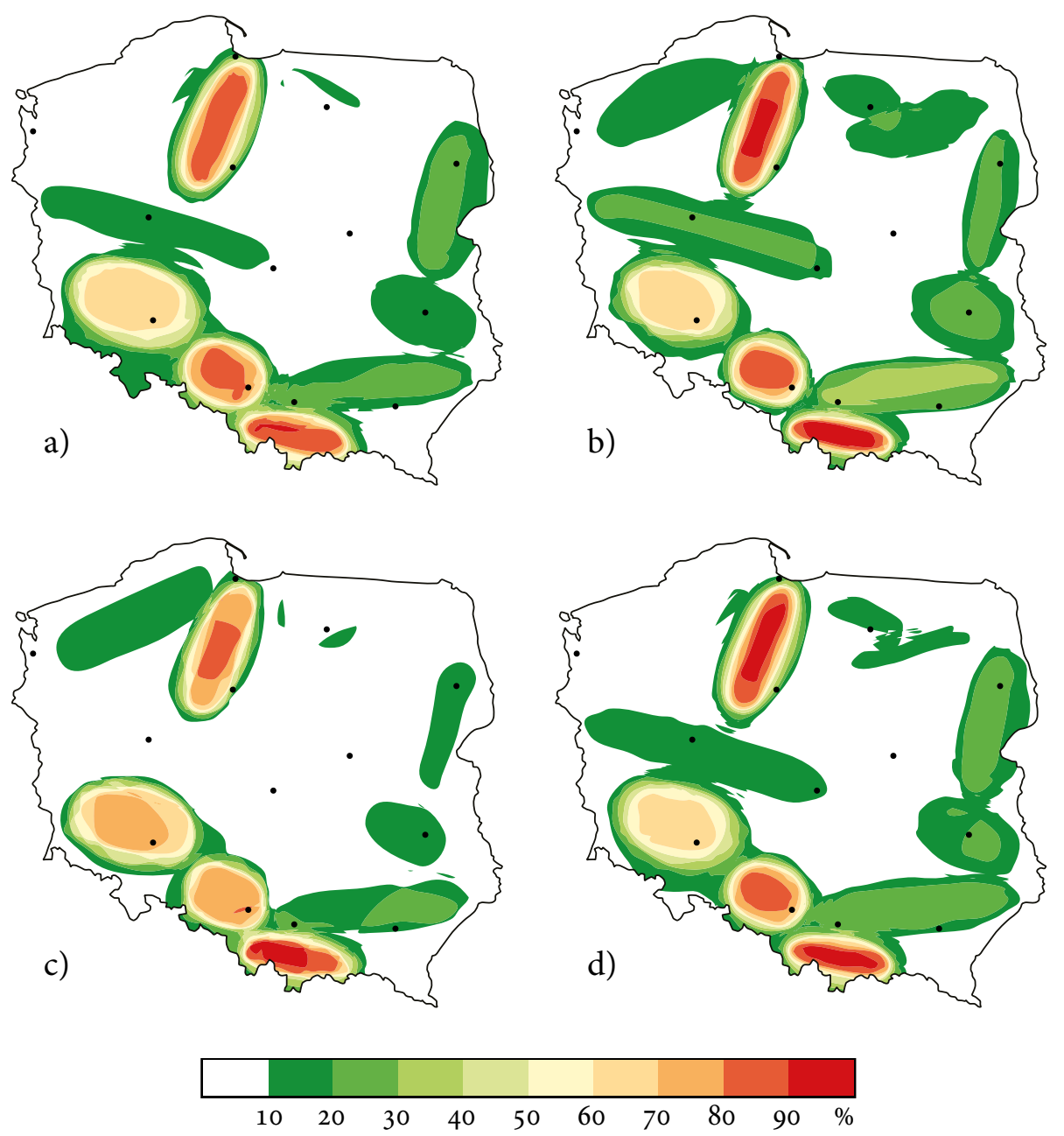

Figure 3. Regions maps filled in by: a) only women (50 respondents), b) only men (35), c) only people born and raised in Lublin (21), and d) only people born and raised in the Lublin voivodeship but outside Lublin (64)

Now, let us take a look at the final composite map (Fig. 5b), again in the clockwise order and starting from the north.

Kashubia was marked by more than $80 \%$ of the respondents. This is as justified as it is in stark contrast to the cities map (see section 5 for a comparison of the two). Warmia and Masuria were both marked by less than $20 \%$, which is consistent with the cities map but somewhat at odds with the findings of Polish dialectology. I suspect that very few Lublinians have actually had contact 
with the spoken dialect because whenever they did speak to the inhabitants of Warmia or Masuria, I expect both would much more often than not use the literary standard or at least their best approximation of it. As also, I imagine, was the case with Mazovia which was marked by less than $10 \%$ of the respondents. Podlachia proved to be a little more recognizable, possibly because the east of the country is seen by some as preserving to a greater or lesser extent the dialect of pre-war eastern Poland (modern Lithuania, Belarus, and the Ukraine). It is interesting then, that the Lublin region was marked by as many as between 10 and $20 \%$ of the respondents from this area whom I would expect to be well aware that their own speech does not very much resemble this now largely extinct kresowszczyzna. Lesser Poland was marked by fewer than 30\% of the respondents, despite the fact that virtually all classifications of Polish dialects include Lublin inside the Lesser Polish group of dialects (cf. Karaś 2010). Podhale was the most consistently marked region, recognized by more than $90 \%$ of the respondents. This is understandable because it is indeed one of the very few areas in Poland which have preserved their local cultural and linguistic identity to a considerable degree, and which in addition use it very often as a selling point to draw tourism. It is, nonetheless, in very sharp contrast to the cities map. This is unlike Upper Silesia, the only region on which the two maps agree. In the regions map, it was marked by more than $80 \%$ of people, which, too, is an understandable result for a region that is commonly seen as quite willing to emphasize its distinctness. Lower Silesia was only returned to Poland after World War II, having its predominantly German population expelled and replaced with Poles often relocated from territories annexed by the Soviet Union, which resulted in what is usually called a 'mixed dialect', even if it is in fact more a mixture of various dialects (cf. Zielińska 2013). From this perspective it may seem justified that the region was marked by more than $60 \%$ of the respondents, but see below. Greater Poland was only marked by less than $20 \%$, again, at odds with linguistic classifications, which, as far as I can tell, always separate it into its own distinct group. Lastly, Pomerania, just like Lower Silesia, is in reality a mixture of dialects from various regions, but unlike it, it was only marked by more than $10 \%$ of the respondents. There is little linguistic reason for this different treatment. I suspect that many people may have been deceived by its name sharing a crucial part with Upper Silesia, a very well recognizable region.

The percentage of respondents who marked specific regions correlates fairly well $(\rho=0.69)$ with the number of Google results for phrases describing the given dialect (see section 5 , and Table 3 ). The three most clearly marked regions are also the three with the highest number of hits (note that the table does not include phrases with góralski 'highlandese', which return nearly 60 thousand results). The only notable differences are Lower Silesia which was marked by more than $60 \%$ of the respondents even though phrases such as 
dialekt dolnoślaski 'Lower Silesian dialect' are very rare, and Greater Poland for which the situation was reversed. For the former, I suspect the similarity of names with Upper Silesia, as mentioned above. For the latter, I am at a loss for an explanation, even more so that Poznań, as the metropolis, was marked by more than $20 \%$ of the respondents from the Lublin region, and as much as over 70\% from Szczecin and from Poznań itself (Bounds 2010, 2015; Stachowski [forthcoming]). Notwithstanding, the regions map radically differs from the cities map with regard to its accordance with Table 3; see section 5 for a possible explanation.

Overall, the map is fairly consistent with my expactations. The separateness of Kashubia is widely known, Podhale is a touristic region noted for its folklore, and Upper Silesia has by far the strongest autonomy movement in Poland. Mazovia together with Greater and Lesser Poland are often viewed as the core of Polishness, Pomerania together with Warmia and Masuria are primarily connected with holidays by the seaside and the lakes, and the Lublin Region and Upper Silesia do not appear to me to have any particular strong associations. It is only Podlachia that I would suspect a larger proportion of the respondents would mark as perhaps possessing a specific melody to its speech that is more characteristic of East Slavic languages than standard Polish. This appears to have been to some degree the case with Białystok in the cities map (marked by more than 30\%) but not confirmed in the regions map.

\section{Comparison}

Looking at the two maps in Fig. 4, it is difficult to believe that they come from the same study. The differences between the sexes and those resulting from where the respondents were born and raised (Figs. 2 and 3) appear to be virtually non-existent in comparison. ${ }^{1}$ Nonetheless, it seems that they are not too difficult to explain. My interpretation is based on an argument in three parts, and suggests that the regions map is eventually closer to the truth.

The first part of the argument is the assumption that a sizeable portion of the answers in the questionnaire was to a non-insignificant degree dictated by whether the phrase 'the dialect of ...' sounded familiar to the respondent. A word of explanation. In the Polish tradition, dialects are named after where

\footnotetext{
${ }^{1}$ One of the reviewers of this paper called for a more precise measurement of the differences between the various maps produced in the experiment, such as $p$-values. Unfortunately, it is not clear to me how this concept can be sensibly and profitably applied to maps such as ours. Lameli, Purschke and Kehrein (2008) make use of $p$-values, but only to see whether individual respondents marked a different number of areas depending on what type of map they were given, and not whether those areas were on the whole any different, which is what would be my goal here.
} 
they are spoken (not, e.g., after a prominent phonetic feature), and the distinction is usually tripartite: język 'language' vs dialekt 'dialect' vs gwara 'subdialect'. The term dialekt is typically reserved for larger, regional varieties, and well-known also among laymen, while the term gwara tends to be only used for the dialect of a single city, and it is considerably rarer outside lingusitic parlance. It is difficult to gauge precisely the commonness of phrases such as dialekt mazowiecki 'the Mazovian dialect' or gwara warszawska 'the subdialect of Warsaw'. Here, I decided to resort to Google to obtain the approximate numbers. I admit that this may be a precarious argument - especially that some of the values were different when I checked again just a day later - but the differences in the magnitude seem to be nonetheless quite convincing. The combined regions map follows them fairly closely $(\rho=0.69)$ but the cities map does not at all $(\rho=-0.08)$; see Fig. 4 . I believe that this is mostly due to the more technical nature of the term gwara, and in fact quite consistent with my interpretation as a whole (see below).

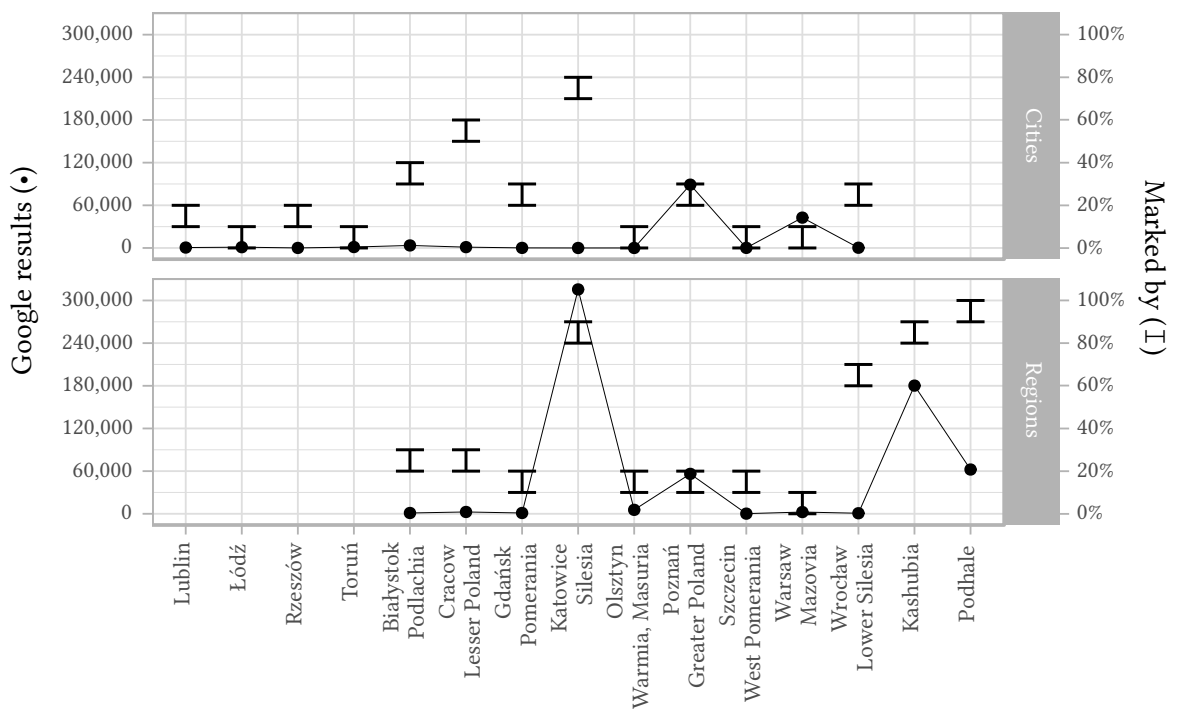

City/Region

Figure 4. The percentage of respondents who marked the different cities or regions (errorbars I), contrasted with the number of Google results for the Polish name of the respective dialect (points •; accessed 2017.08.30), combined for gwara 'subdialect', dialekt 'dialect', and język 'language. Compared to the maps in the questionnaires, three minor changes have been introduced here for readability: Warmia and Masuria have been combined, while Pomerania and West Pomerania have been split; the Lublin region (Ziemia lubelska), on the other hand, has been omitted because it does not have a separate adjective in Polish. In addition, Silesia (gwara ślaska, dialekt ślaski) is assumed to primarily refer to Upper Silesia, and the number for Podhale includes phrases with góralski 'highlandese' which counted 57,541 results 
For the second part of the argument, let us compare the two maps directly (see Fig. 5). The one point in which they agree is Silesia. I propose that this is because Silesia is known for its separateness, the phrase dialekt ślaski is quite frequent - and Katowice is strongly associated with Silesia. The two main points in which the maps disagree are Podhale and Kashubia. Podhale is perhaps also readily associated with one town, Zakopane, but it was missing from the cities map and it is a smallish settlement which could easily have escaped my respondents. Kashubia, to the best of my knowledge, is not commonly associated with any particular place, and none of its towns featured in the cities map. Regardless, more than $30 \%$ of the respondents drew an ellipsis in the vicinity of Gdańsk which, I believe, was in most cases meant to refer to Kashubia, not to the city itself. Regarding the already less striking differences in the treatment of Cracow and Wrocław, see sec. 3, and below, respectively.

Lastly, as the third part of the argument, I should like to note that the regions map is overall more decisive than the cities map (see Fig. 5). It has some areas marked by 10 or $20 \%$ of the respondents but, with only the exception of Upper Silesia, when a region is more clearly marked, it is marked by more than 80 or $90 \%$ of people. In the cities map, the most distinctly marked area was selected by more than $70 \%$ of the respondents (Lower Silesia), and all the others are marked by usually less than a half of the group. I believe this fact can well be interpreted as a sign of hesitation (i.e. different answers from different respondents, balancing each other out to some degree) which results from the lack of familiarity with phrases such as gwara poznańska \& c., and with the notion of city-specific subdialects in general.

I believe that these three points, when put together into a single argument, explain the three most striking similarities and dissimilarities between our two maps. The fourth significant difference is Lower Silesia but this, as mentioned in section 4 above, is probably to be attributed to the similarity in names with Upper Silesia, and gaps in education.

The other areas were all marked by fewer than a third of the respondents, with just one exception for Białystok in the cities map, and are fairly similar in both maps. It is not clear to me whether anything should be construed from the fact that significant differences are all located in the 'red' parts of the map.

\section{$*$}

I want to make one more small observation. In the cities map, most respondents drew an ellpisis approximately around the name of the city. In some cases, they also marked an unlabelled region, and it was only very rarely that they would limit themselves to just underlining the label. ${ }^{2}$ In the regions map, the

${ }^{2}$ Such cases have also been included in the combined map. I simply drew a circle around the city myself, assuming that this is what the respondent meant by their answer. 
majority of answers were also ellipses around labels, but the proportion of just underlined labels was much larger, at the expense of answers which marked an unlabelled region.

It would be interesting and informative to repeat this study, only this time using questionnaires with just lists of cities and regions on them instead of maps. Based on this experiment, it would seem that translated to a map, the cities part could look different but the regions part could be perhaps almost identical.
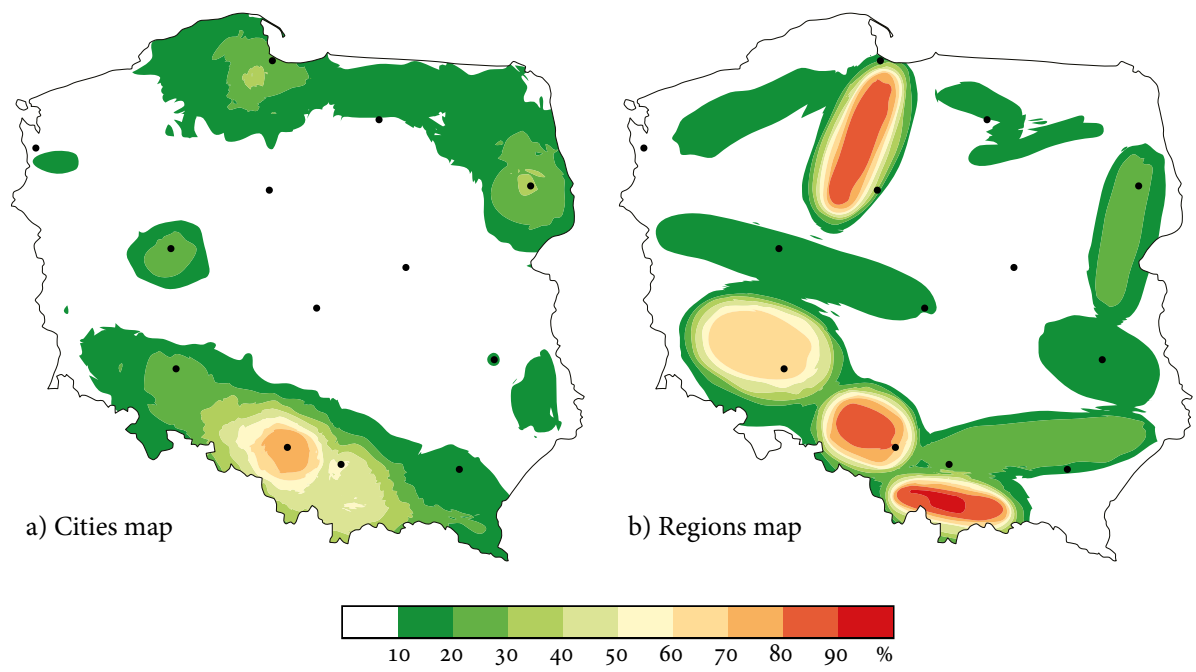

Figure 5. Composite maps of all the respondents in a) the cities map part of the experiment, and b) the regions map part

\section{Summary}

The paper discusses an experiment in perceptual dialectology where two groups of students were given maps of Poland and asked to "mark areas where people speak differently than in the rest of the country". One group received a map with thirteen major cities labelled on it, the other a map with twelve of the main geographical and historical regions. Their answers were combined into single contour maps which proved to have very little in common with each other.

The "cities map" is briefly compared in section 3 with maps obtained in similar studies in Poznań (Bounds 2010, 2015) and Szczecin (Stachowski [forthcoming]), and proves to be fairly similar, suggesting that there is relatively little variation in Poland in the perception of the dialectal diversification of the country. 
There is, to the best of my knowledge, no study to which the "regions map" (section 4) could be compared. Its results agree quite well with the expectations and, interestingly, correlate fairly well with the number of Google results for phrases such as dialekt podhalański 'the Podhalan dialect', \& c.

In section 5 , it is argued that in our particular case, the regions map more accurately reflects the common opinion because in the Polish tradition, dialects (dialekty) are typically ascribed to and named after entire regions, and are talked about more often than subdialects (gwary) connected with specific cities. This is supported by the fact that the regions map only truly agrees with the cities map in one point which is the region of Silesia, readily associated with the city of Katowice that was labelled in the cities map - while the other linguistically distinct regions either do not have such emblematic towns or they were missing from the cities map.

I do not believe that this result can be automatically extended to other languages and countries. Maybe similar results would be obtained e.g. in Germany or Italy, but e.g. English certainly has its own and very different specificity. At any rate, the main conclusion from the experiment discussed here is that what labels are present on the map handed out to be filled in is by no means an unimportant design choice and needs to be carefully investigated for each language before valid conclusions can be drawn from previous and future studies.

One more observation that can be made from the data presented here is that, especially in the case of the regions map, respondents tend to only focus on the labels in the map and sometimes go so far as to only underline labels without even encircling regions. It would be interesting to compare this result with a study in which respondents are given just a list of regions and no map at all. Should the results prove similar, this could undermine the very validity of the draw-a-map method.

\section{References}

Alhazmi Leila (2017). A perceptual dialect map of Western Saudi Arabia. White Rose College of the Arts \& Humanities. Student Journal 3, 2-16.

Bounds Paulina (2010). Perception of Polish speech varieties. Poznań Studies in Contemporary Linguistics 46(2), 155-176.

Bounds Paulina (2015). Perceptual regions in Poland: An investigation of Poznań speech perceptions. Journal of Linguistic Geography 3(1), 34-45.

Bucholtz Mary, Bermudez Nancy, Fung Victor, Edwards Lisa, Vargas Rosalva (2007). Hella Nor Cal or Totally So Cal? The perceptual dialectology of California. Journal of English Linguistics 35(4), 325-352.

Calaza Díaz Laura, Suárez Quintas Soraya, Crujeiras Rosa M., Rodríguez Casal Alberto, Sousa Xulio, Ríos Viqueira José Ramón (2015). A method for processing perceptual dialectology data. In Actas XII Congreso Galego de Estatística 
e Investigación de Operacións. Lugo, 22-23-24 de outubro de 2015, María José Ginzo Villamayor, José María Alonso Meijide, Luis Alberto Ramil Novo (eds.), 282-291. Lugo: Universidade de Santiago de Compostela.

Cukor-Avila Patricia, Jeon Lisa, Rector Patricia C., Tiwari Chetan, Shelton Zak (2012). “Texas - it's like a whole nuther country": Mapping Texans' perceptions of dialect variation in the Lone Star State. Texas Linguistics Forum 55, 10-19.

Demirci Mahide (2002). Gender differences in the perception of Turkish regional dialects. In Handbook of perceptual dialectology, vol. 2, Daniel LonG, Dennis R. Preston (eds.), 41-50. Amsterdam-Philadelphia: John Benjamins.

Geržotaité Laura, ČePAItiENĖ Agnè (2016). Vilkaviškio jaunuolių kalbinè gimtinė: ribos, taisyklingumo ir patrauklumo vertes [Linguistic homeland of the young people living in Vilkaviškis: Borders, correctness and attractiveness]. Verbum 7, 84-100.

Gould Peter, White Rodney (1986). Mental Maps. $2^{\text {nd }}$ edition. London: Routledge.

Lameli Alfred, Purschke Christoph, Kehrein Roland (2008). Stimulus und Kognition. Zur Aktivierung mentaler Raumbilder. Linguistik online 35(3), 55-86.

KARAś Halina (2010). Zasięg terytorialny i podziały dialektu [URL: http://www.dialektologia.uw.edu.pl/index.php?l1=dialekt-malopolski-zasieg; accessed August 30, 2017].

KocH Günter (2009). Perceptual dialectology and dubbing of dialects. In inTRAlinea Special Issue: The Translation of Dialects in Multimedia, Michela Giorgio MarRANO, Giovanni NAdiani, Chris Rundle (eds.) [URL: http://www.intralinea.org/ specials/article/1721; accessed August 2, 2017].

Montgomery Chris, Stoeckle Philipp (2013). Geographic information systems and perceptual dialectology: a method for processing draw-a-map data. Journal of Linguistic Geography 1(1), 52-85.

NSP = Główny Urząd Statystyczny Polskiej Rzeczypospolitej Ludowej. 1955. Narodowy spis powszechny $z$ dnia 3 grudnia 1950 r. Miejsce zamieszkania ludności $w$ sierpniu $1939 r$. Warszawa.

Preston Dennis R. (1989). Perceptual Dialectology. Nonlinguists' Views of Areal Linguistics. Dordrecht, Providence: Foris.

Stachowsкi Kamil [forthcomig]. Przyczynek do dialektologii percepcyjnej Polski: Szczecin. Język Polski.

Theodoropoulou Irene, Tyler Joseph (2014). Perceptual dialectology of the Arab World. Al-Arabiyya 47, 21-39.

WÜrTh Melanie (2014). Cartografías de la ciudad. Representación y estilización lingüística en mapas mentales de Buenos Aires. Boletín de Filología 49(2), 311-349. Zielí́ska Anna (2013). Mowa pogranicza. Studium o językach i tożsamościach w regionie lubuskim (= Język na Pograniczach 41). Warszawa.

\section{Appendix}

In order to preserve compatibility with Stachowski [forthcoming], and also to reduce the number of variables as much as it is possible, the main part of the present study was limited to a specific age group, level of education, and geography; see section 2. However, this means that about a half of the collected questionnaires were excluded (68 out of 160 in the cities part, and 106 out of 
191 in the regions part). Therefore, in order not to waste otherwise perfectly good data, I briefly present them below with a rudimentary discussion. The combined maps are given in Fig. 6.

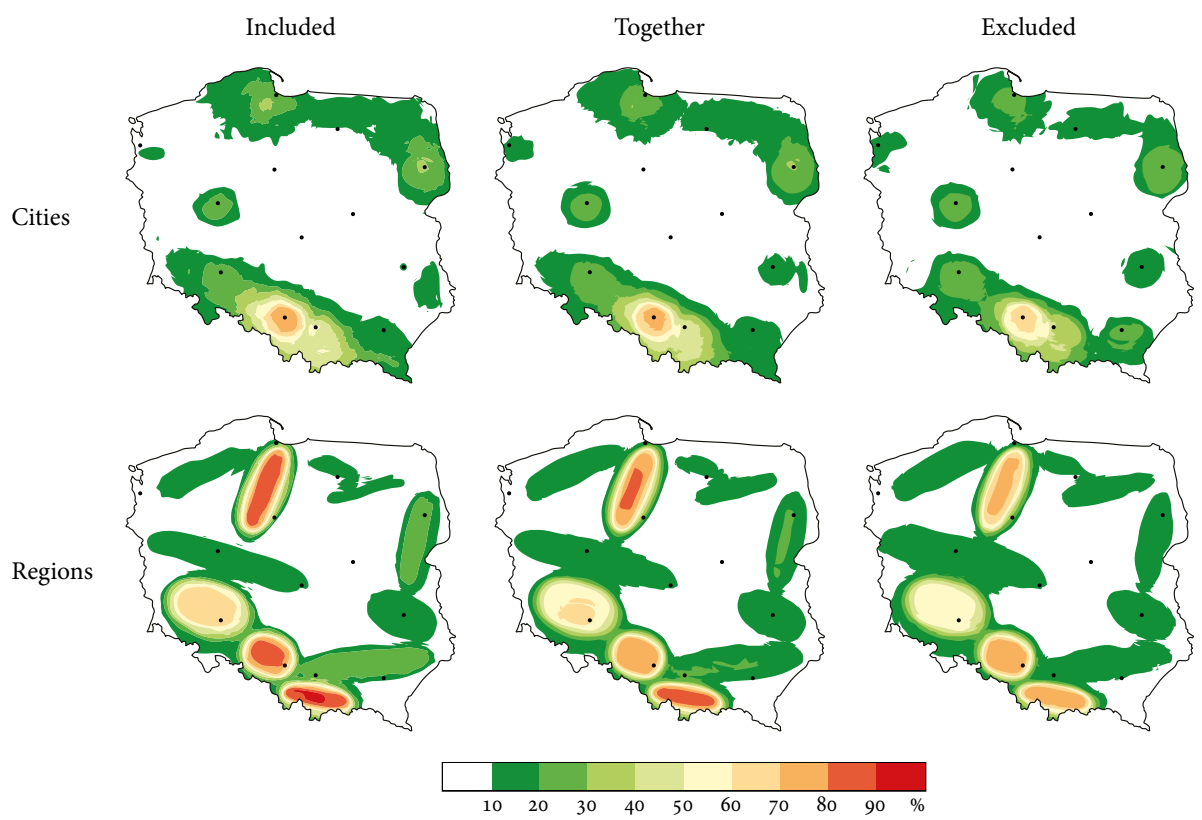

Figure 6. A comparison of the questionnaires included in and excluded from the main part of the paper. The middle column are maps combined from all of the forms collected in the study

There is in fact very little difference between the maps combined from the answers included in the main part of the study, and those excluded from it, both in the cities and the regions part of the experiment. The two are certainly more similar to each other than to the results of the Szczecin study. The main difference, visible quite clearly in both parts, is that the maps based on excluded answers are less filled, less 'mountainous', or, as it were, less decisive.

I believe that the explanation of this phenomenon is fairly straightforward. By far the most frequent reasons for exclusion were that the respondent was not born or not raised in the Lublin voivodeship (see Tables 1 and 2). A comparison of the maps produced here with the maps from Poznan and Szczecin studies (Bounds 2010, 2015; and Stachowski [forthcoming]) shows that both these factors can and do influence the perception of dialectal diversification in Poland. ${ }^{3}$ The maps presented in the main part of the present paper were distilled

${ }^{3}$ Bounds included in her study all the answers she collected, which makes her results more comparable to the middle than to the rightmost column in Fig. 6 here. Still, the majority of her respondents were from the Greater Poland voivodeship (Bounds 2010: 160, 2015: 38) and therefore her study can be used, if with lesser force, in this argument. 
with regard to geography, whereas the ones excluded from it are mixed. The proportion of respondents who were neither born nor raised in the Lublin voivodeship ranges from $54 \%$ in the cities part to $63 \%$ in the regions part, but even they have at least spent some time there recently since they study or, in a handful of cases, work in Lublin itself. The excluded questionnaires can thus be described as a mixture of a variety of influences with a particularly strong Lublin component. When combined, the different regional perceptions balance each other out to a certain degree, and the net result is effectively a diluted version of the purely Lubinian maps presented in the main part of this paper.

I included approximately as many answers as I excluded. It is to be expected, then, that the maps combined from all of the answers I collected would be something like the average of the two. To better highlight this result, I present them in the middle column in Fig. 6, between the maps combined from questionnaires included in the main part of the study on the left, and from rejected answers on the right.

I suppose that the next step should be to assess the relative import of the place of birth, childhood residence, and the place of residence. Of course the fact of being born in one place or another in itself cannot possibly influence the perception of dialectal variation but I suspect that in many cases this question revealed a place where the respondent spent some part of their childhood, just not the greater part. It will be perhaps advisable to broaden the social background section of the questionnaire, and include a question about the period of residence in the area of interest.

Instytut Językoznawstwa Uniwersytet Jagielloński

al. Mickiewicza 3

31-120 Kraków

[kamil.stachowski(at)uj.edu.pl] 